\title{
Malkom Khan's Approach Toward Political Modernization from above in Iran
}

\author{
Kamyab Shahriari (Corresponding Author) \\ Department of Government and Civilization Studies, Faculty of Human Ecology, University \\ Putra Malaysia (UPM) \\ Serdang, Selangor, Malaysia \\ E-mail: shahriarikamyab@gmail.com
}

Received: December 3, 2016

Accepted: December 6, 2016 Published: June 25, 2017

doi:10.5296/ijch.v4i1.10196

URL: https://doi.org /10.5296/ijch.v4i1.10196

\begin{abstract}
Malkom Khan (1833-1908) was a very significant scholar in the Qajar and constitutional era and the first to propose political modernization in order to change the traditional structure of government and replace it with a new and modern one. He was aware of the fact that Iran's backwardness and chaotic situation was the result of the traditional and despotic political structure of government. This paper examines the political thought of Malkom Khan and his approach toward modernization of the political structure of government in the first period of his political life as activist and theorist. Research shows that his approach toward the political modernization program was political modernization from above or in other words, a form of state-building. His strategy to accomplish this goal can be described as getting Iranians to accept western civilization and the principles of order without changing them.
\end{abstract}

Keywords: Iran, Political modernization, intellectuals, Malkom Khan, Constitution

\section{Introduction}

The move toward modernization in Iran began as military modernization in the era of Abbas Mirza and then reached the level of bureaucratic modernization in the era of the Amir Kabir premiership. However, the first person to propose a specific plan for political modernization from above was Malkom Khan (1833-1908). Malkom khan was a prominent intellectual who tried to limit the authority of the despotic ruling system and change it into a law-based government system. His aim was to create a new ruling institution by establishing modern departments, political modernization, law-based government and separation of powers.

Malkom Khan's ideas for change in the structure of government were the first signs of a theoretical struggle to oppose the long-lasting and long-established despotism and replace it 
with basic individual, political and social rights under a law-based government. All these factors made Malkom Khan realize that despotism was the main reason for the chaotic situation of Iranian society and his proposed modern reformist theories and his modernization program was with the goal of improving the political structure of the government. This paper is to investigate Malkom Khan's thoughts on political modernization to uncover his approach on political modernization from above in the first period of his political thought,

\section{Malkom Khan and Law-based Government}

Since the type of government has close connections with the degree of differentiation and specialization of political structure, as Almond and Powell pointed out, Malkom Khan also attempted to propose a law-based government in Iran. Description of government and explaining its different types is one of Malkom Khan's theoretical subjects in an essay titled Ketabcheh ye-Gheibi (A book inspired by an unseen world) or Daftare Tanzimat (The book of reforms). This latter treatise, which is one of Malkom Khan's oldest written works, was written in 1861. Malkom Khan wrote about the necessity of law and order in the Iranian government system, in addition to examining the reasons for development in western countries. Malkom Khan believed that all aspects of political, economic, industrial and social developments in European and western countries were the result of order in their government system. He asserted that Iran's government is the first government capable of accepting any kind of order in its government system. He states this in order to justify the practicality of his proposition in the reader's mind beforehand and makes reference to how in Iran, the King is ranked first, followed by the government officials and continues by describing bitterly the miserable situation of Iranian society and believes:

When somebody compares the situation of Iran with western countries, he is shocked to discover how inefficient the governmental officials of Iran are, considering all natural blessings granted by God to Iran; this country is so miserable and helpless (Mohittabatabaei, 1948, p. 11).

Following his analysis of the root of Iran's disorder and backwardness and also the barriers to its development, he believed explicitly that the reasons why European countries were developed was because of the miracle of their government system, political structures, and type of government. He believes that Europe has advanced by virtue of possessing two kinds of 'factories', one for producing goods and the other for producing educated, trained individuals. According to him "they take in ignorant children and turn out engineers and accomplished thinkers" (Asil, 2002f, p. 28). Malkom Khan deeply believes that Iranians are only aware of the first kind of 'factory' but they are completely unaware of the wisdom of the westerners in having the second kind of 'factory', namely educational and human resources development systems in all its various forms.

He placed his priority on the 'human factory' since, he had planned modernization program from above and believed that "what Iranian society needed most is the human factory such as: factory of tax, factory of armies, factory of justice, factory of science, factory of security, factory of order and so on" (Asil, 2002f, p. 29). within the 'factory of humans' he considers another kind of factory by the name of dastgah-e divan (government) and believes that in 
European countries, there is one 'factory' that is located in the center of the government system, which stimulates other 'factories' and that this great system or factory called dastgah-e divan determines the entire progress of Europe (Saeedi, 2002). Malkom Khan expresses that in such a situation, equipping Iran with human training 'factories' is a priority and just like reforms, it starts from the above. He explained this as the priority action that Iran needed. After mentioning these introductions, Malkom explains the different kinds of government. In describing the government, Malkom Khan says: "One regime which is the source of dictating throughout the nation is called government” (Akbari, 2003).

Then he goes on to mention different kinds of government. In his opinion, governments are classified into two groups, republican and monarchies. He also divides monarchial government into two types: first; absolute monarchy (with law as the basis and method of its operation) (saltanate motlaghe ye montazem) and second; constitutional monarchy (sultanate mashroote).

In Malkom Khan's opinion, absolute monarchy is a kind of government which has both the authority of establishment and execution of law and is united in the hands of an absolute king, like the monarchy of Russia and Ottoman. Constitutional monarchy on the other hand, is a form of government where the authority and establishment of law is in the hands of the executive and the king is largely a symbolic leader, as in England and France (Adamiyyat, 2009).

Malkom Khan declares that constitutional monarchy is not suitable for Iran. He believes that absolute monarchies can be divided into two types based on legal aspects: law-based absolute monarchies (sultanate motlagheye montazem) and (sultanate motlagheye gheyre montazem) or lawless absolute monarchies (Asil, 2002f). To explain the difference between these two kinds of absolute monarchy, he states that in lawless absolute monarchies, rulers do not understand the difference between the duties of establishing laws and executing laws and so, they perform both duties together.

Malkom Khan believes in a lawless absolute monarchy (saltanate motlagheye gheire montazem) in which ministers always controlled the monarch. This is because when carrying out the will of the king by obeying his order, executing that order is given only to one person, and this person fulfills the king's wishes but in a way that he thinks is best (Gheisari, 2004). Malkom Khan also refers to a very pertinent point that, in parliament, the duties of enacting laws and executing laws were combined, so non-separation of duties caused it to be inefficient. Therefore it can be concluded that law-based absolute monarchy (motlagheye montazem) is a kind of government based on law, contrary to absolute monarchy, which is totally autocratic.

He mentions absolute monarchy as a kind of government which is based on injustice and tyranny, taking people's possessions by force and utilizing it for personal interests. A very important and vital point in Malkom Khan's thinking about government is his detailed description of the nature of monarchy and government in relation to law. He was well aware of the problems that can result from the enacting and executing of laws under the control of only one person. As such, he attempts to invite readers gradually to realize the necessity of 
guiding political thought and the monarchy toward limiting the authority of the monarchy and prepare to take the authority of enacting laws from the hands of the monarch and giving it to the legislature, by describing different kinds of absolute monarchy.

\section{Law-Based Absolute Monarchy (Sultanate Motlaghey-e-Montazem), Malkom Khan's Ideal Political System for Iran}

Naser al-din Shah was interested in making some changes in his government system and its political structure and empowering his monarchy by these changes. This made him interested in gradually getting acquainted with some of the political ideas about government. Malkom Khan was aware of this situation and of the necessity to present an ideal governmental model for Iran of that time. He knew well that it was impossible to talk about the necessity of limiting the power of the monarchy. Thus, without specifying the name and form of government, Malkom Khan attempted to exploit Naser al-Din Shah's ready mental state by presenting a theory about government and led the King to accept the accomplishment of two goals: government regulation and revising the government political structure; and a modified authority for the monarchy with separation of power between executive power and legislative power.

To achieve all the above-mentioned goals, he was determined to introduce the ideal form of government for Iran after studying different kinds of government, Malkom Khan states explicitly, though briefly, that the ideal government for Iran at the time of Naser al-din Shah was neither a constitutional government nor an absolute one, but rather a law-based absolute monarchy (sultanate motlagheye montazem) (Goodarzi, 2008). Malkom believed that constitutional monarchy was not suitable for Iran. What Iranians needed was an absolute monarchy, like Russia, Austria and Ottoman. Although Naser al-din Shah had both authority and duties of government, for observing the order of government and preserving his own power, the Shah never used these two authorities together. The kings of Russia and Austria never delegated their ministers to both enact laws and execute them as these two duties are completely different (Goodarzi, 2008).

Although Malkom Khan declares and emphasizes that sultanate motlaghe ye- montazem (law-based absolute monarchy) is the best form of government for Iran, he also states that conducting Iran's government is based on law, even though he accepts the absoluteness of monarchy. But by this proposition, he wants the government to be based on law; In other words, he accepts absoluteness of the monarchy but refuses to accept its lawlessness. Malkom Khan, from the onset had opposed despotism but he made sure not to openly declare his opposition explicitly.

By having higher knowledge about the mechanism of despotism compared to the other intellectuals of his era, Malkom Khan attempted to prove that lawless absolute monarchy destroys the authority of the despotic king by spreading disorder and chaos. He declared that as in all lawless absolute monarchies (salatanate motlagheye gheire montazem) in Asian countries, two authorities to enact laws and execute them are combined, but the ministers execute the order of the king according to their whims. Thus, these ministers prevent the government from being law-based (Ajdani, 2007). 
Malkom Khan's solution for this problem was the establishment of two separate structures, implying a separation of powers. The system of legislating and the system of executing that were introduced in his proposal were majlise tanzimat (the reform council) and majlise vozara (the council of ministers) (Adamiyyat, 2009). In other words, one of his main goals was to inculcate gradually the thought of separating powers. So, he proposed the system of separating powers for the first time in Iran, which will be discussed in detail later.

\section{Duties of the Government}

Discussion about the duties of the government is related to the theoretical political debates of Malkom Khan. Traditional and ancient thinkers of Iran have often emphasized the duties of the rulers such as security, protection of borders, guarding the roads and security of suburban traffic, justice and other duties. First, it must be made explicit what duties Malkom Khan had presumed for the government. Then the origins of his ideas will be examined in this context. In Malkom Khan's opinion, government duties can be categorized into: "protection of independence, protection of human rights, and protection of economic rights" (Asil, 2002a).

Compared with the host of duties which the ancient thinkers and scholars of the Qajar dynasty had proposed for the government, Malkom Khan limited the duties of the government to the above three duties. This limitation of government duties was one of the most tangible concepts that Malkom Khan borrowed from European philosophers, especially the ideas of John Locke. New political philosophers of Europe influenced by the ideas of the bourgeoisie, limited government duties to a minimum in order to meet the political and governmental objectives of the powerful class.

\section{Creation of Parliaments}

Creation of parliament is an indicator of political modernization, as Almond \& Powell mentioned it leads to differentiation and specialization of political structure. To do so, Malkom Khan postulated two types of parliaments in the structure of absolute law-based monarchy for modernization of the political structure. The two kinds of parliaments proposed were the reform council (majlise tanzimat) and the council of ministers (majlise vozara), both of which were to be presided over by the King.

\subsection{The Reform Council (Majlis-e- Tanzimat)}

Malkom Khan, in line with law- based absolute monarchy (sultanate motlaghaye montazem) introduced the Majlis Tanzimat as a legislative organ and described its duties. In a law-based absolute monarchy, government laws are enacted in this Majlis but no decree may be issued out of these laws, except when something happens due to these laws and in such a situation, government orders are decreed by the order of the king. According to Malkom Khan, the council is in charge of determining all general matters such as ministers' duties and salaries and issues related to the army, commerce, agriculture and prosperity of the country, and these have to be approved by the King (Isa Nia, 2001). The Majlis is composed of the monarch, three princes, fifteen advisors and eight ministers and the right to appoint and dismiss its members is vested in the king (Ajdani, 2007). Decrees of Parliament must be signed by at least ten advisors. In addition, this Majlis is in charge of supervising the proper execution of 
laws. Investigating people's complaints about the misbehavior of government officials is also one of the duties of the Majlis.

The King appoints the head of the Majlis and is known as "Sadrol Mashverah"or Great Advisor. This reform council will review the laws pertaining to religion and government within the period of one year, and examine their legality for incorporating them in the laws of the state (Adamiyyat, 2009). In Malkom Khan's proposal the parliament was to legislate in five general fields: legal issues; governmental organizations; penal issues; governmental instructions and directives; and executive regulations and procedures (Aryanpour, 2000). In addition to the reform council (majlise-tanzimat), which is located in the capital and makes decisions at national level, Malkom Khan also proposed some provincial legislative parliaments (majalise-tanzimat) within the law-based absolute monarchy that was to be established in each province. This provincial institution would comprise a ruler, sheriff and twelve trusted individuals of the province. The duties of this parliament are as follow. Dividing the taxes of the province, enacting government laws, supplying food for the province, constructing and protecting government buildings, determining value of goods and overseeing the implementation of law (Safari, 1998).

The chairman of the provincial legislative parliament is the ruler of each province and this parliament is allowed to collect province taxes with the permission of the country minister and country legislative parliament. In fact, the duties of the legislative parliament are limited to legislating and overseeing the implementation of laws, but it is not allowed to interfere in government duties (Asil, 2002f). In Malkom Khan's proposal, legislative parliament was to be formed to separate the authorities enacting laws and those who implement them, without one body interfering with the work of the other in order to ensure independence. Those appointed to the legislative parliament should be honest, trustworthy and efficient. Speeches in this parliament should be kept confidential but in the reform council (Majlis) the speeches could be made public. Parliament members had equal right to express their opinions. Nobody was allowed to interrupt when others were delivering their speeches. All members of the legislative parliament had the same rank and the order of speaking was controlled by the head of parliament. Expressing opinions was in two ways, implicitly and explicitly. A decree of parliament could be enacted if more than half of the members voted in favor of it. According to Malkom Khan, establishment of the reform council was to strengthen the institution of the monarchy and not to reduce the power of the monarch (Asil, 2002a).

\subsection{The Council of Ministers (Majlis-e-Vozara)}

In Malkom Khan's proposal for the structure of saltanate motlagheye montazem (law-based absolute monarchy), the council of ministers or the cabinet is introduced to help modernize the political structure and also to implement the laws. This parliament is composed of the Justice Minister, Foreign Minister, Interior Minister, Minister of science, Minister of commerce, Minister of Finance and Court Minister. The King is the chairman of the Council of Ministers while the Prime Minister controls the situation of parliament (Sadr-e Azam) responsibility and Ministers' first duty is to execute laws (Asil, 2002a) .

All must act in accordance with the law. Any minister who acts breaks the laws is considered 
a traitor to the government and investigating such traitors is the duty of the reform council.

\section{Nation-State}

Malkom Khan was the first intellectual who understood that despotism was synonymous with being stateless. He believed that the obvious weaknesses of Asian countries are the mixture of two functions of rule. Others have written much about the advantages of separating these functions. The point to be mentioned is that without this separation neither order nor government will exist (Asil, 2002a). And in Malkom Khan's view, the establishment of the state must have a strong relation with the separation of the legislative from the executive branch.

The basis of order and meaning of state lies in this fact. The most important reason for not benefiting from the establishing of parliaments is that these two duties (legislative and executive) are combined and until these are separated in Iran, as they should be, all of the efforts would not have any benefit except being about disorder and inefficiency (Malkom Khan, 1870a). According to him, a poem is the result of factory of reason and order in the state is the result of the factory of law (institution of law). There is no factory of law (institution of law) in Iran and without this factory (institution) Iran will have neither order nor a viable state (Malkom Khan, 1870d).

He pointed out that a political system will not be established if the government's power is dependent on one man's will. Whenever the kings of Iran had thought about establishment of order in the state, they had thought only about their own era and made others dependent on themselves. So, as long as they were alive and remained as heads of state, there is a sort of order in government. But, as soon as they die, no sign of state order remains, as all powers had been vested in them (Malkom Khan, 1870b). In his view these kinds of temporal rules cannot be called a government system or state. The real government system is a system that endures even after its founder dies and continues to become even more stable.

While Malkom Khan proposed the establishment of a government by creating a system based on law, he insisted on government with strong powers as well. It was his belief that "each governmental decree which is not supported by military power won't have any result except the shame and humiliation of its writer"(Malkom Khan, 1876a, p. 170). Therefore, Malkom Khan attempted to establish a law-based absolute monarchy (sultanate- motlagheyemontazem) or a government based on law. He wanted to establish a political system to make the people aware of their political rights. He pointed out that Iranians' mistake is that they think government regulation and order is due to the kings' wisdom and reason, while, except in Russia, the order in government systems have been completely the result of people's wisdom and reason" (Malkom Khan, 1876b, p. 173).

By creating a political relationship between state and nation that is through the establishment of a nation-state Malkom Khan says:

Iranian gentlemen and nobles think the purpose of government is to preserve aristocrats and noblemen's families. The masses think that the government should give them all of their rights. On the one hand, Iranians do not know at 
all what they should demand from their government and on the other hand, the government does not know what should be given to the people too. So, as a result of this disarray and disorder, the rights of government and people and their tasks and duties are indefinite and confused. It is observed that the Iranian government is often performing some works or duties which do not have any relation to its tasks and duties and on the other hand, the nation expects some duties from government which are completely irrelevant (Asil, 2002a, pp. 114-115) .

Malkom Khan viewed the ambiguity, bewilderment and disorder in the relationship between state and people in Iran by considering the kind and quality of political relationship between the government and the people in western countries and he suggested a political relationship based on nation-state instead of the existent relationship in Iran. He wrote in the treatise of clergyman and minister (Sheikh-va-Vazir) on behalf of a minister willing to support legislation and compares two different government structures in the past and present and pointed out that:

In the past it was enough for the development of government to have educated officials, but now it is not the same. At present the basis of government development is in a way that in addition to educated ministers people should be educated and be aware as well (Asil, 2002c, p. 394).

In his opinion, the power of the government depends more on the people's knowledge and consciousness. He believed a government like the Abbasid Caliphate was established by wise men. But a government like that of England and France cannot be established by wise ministers. In his view the government of Abbasid was a result of the thoughts and deeds of wise men, but the French government was the result of training and education of all people. He believed that, "Having a government like the Abbasid Caliphate was thus not suitable, but rather, Iran must have a government like those of France and England" (p. 395). The type of government which Malkom Khan desired to be established was a government based on the concept of nation-state.

He believed that this new structure of government, that is, a government based on law, was more useful for the government than the nation. Here, his emphasis was on establishment of government, as he knew this structure was the basis of unity between government and nation and pointed out that: "The king will benefit more than the nation from establishment of a government based on law. Without the mentioned basis, the proper unity of nation and state is not possible and the efforts of both sides are wasted" (Malkom Khan, 1869).

\section{Creation of Faramooshkhaneh as a Party}

One of the most important indicators of political modernization is the creation of parties or political organizations as Almond \& Powell pointed out. Malkom Khan's Faramosh Khaneh was the first modern political-social organization in Iran. If those treatises may be regarded as Malkom Khan's manifesto directed in the first place to Naser al-din Shah, and secondarily to the members of his court and the ministers of state, the Faramoosh Khaneh may be thought 
of as an organization for putting that manifesto into effect.

The organization was founded in 1857 with the permission of Naser al-din Shah. It was through the Faramosh Khaneh that Malkom Khan entered the field of political activities. This organization was founded according to the model of European secret associations which were prevalent in the $18^{\text {th }}$ and $19^{\text {th }}$ centuries, but they did not have any relation with freemasonry (Raeen, 1980). Faramosh Khaneh is important for reasons such as collaborative social activity, developed political ideology, and its effect on thinking (Adamiyyat, 2009). Malkom Khan had returned to Iran at the end of Amir Kabir's premiership and it was not difficult for Malkom Khan to foresee Amir Kabir's downfall using his political insight. One of the reasons why Amir Kabir had ventured into the field of reform all by himself was because he had banked on the King's support. Malkom Khan attempted to gather and train those who could be organized as the pioneer social-political agents for his political reforms agenda.

In this situation, Malkom Khan followed program of political modernization from above. He tried to organize the political and social elites and also the political training of Dar-al-Phonoon educated men. Malkom Khan wanted to train individuals in the social and political domain who supported the modernization program on the one hand, and on the other hand, he called on the educated class, who naturally were the most suitable ones work in the bureaucracy of government, in order to strengthen those already committed to bring about modernization within the government. During his time in Europe and Ottoman and through contacts with Freemason associations, Malkom Khan became familiar with them and used the same model for his specific goal.

According to those who were in touch with Malkom Khan his intention of founding Faramoosh Khaneh was to train an intellectual class that was equipped to do social services in the government apparatus (Mohittabatabaei, 1948).

Regarding the organizational features, Faramoosh Khaneh was modeled after secret organizations which were founded for the first time during the Great French Revolution to organize the revolutionary movement and also from secret associations which were prevalent in the $18^{\text {th }}$ and $19^{\text {th }}$ centuries. In talking with Wilfred Belunt, Malkom Khan refers to this point:

I went to Europe and studied religious, political and social systems of the West and I learned the spirit of various sects of Christians and the organization of secret societies and freemasonry and I conceived a plan which would incorporate the political wisdom of Europe with the religious wisdom of Asia (Algar, 1973, p. 13).

Also regarding intellectual features, the ideology of Faramoosh Khaneh was mainly indicative of Malkom's learning from the thought principles of the French revolution and French political-social philosophy in the $19^{\text {th }}$ century, especially the principles of universal declaration of human rights and also French ideas of humanism (Ghaderi, 2009). As Malkom Khan knew how difficult it was to preserve Faramosh Khaneh in that social situation, he selected Naser al-Din Shah as its honorary chairman. Yet, Faramosh Khane was very quickly 
and vehemently opposed by the courtiers, officials and also conservatives. Although the lifespan of Faramosh Khaneh was very short and it was shut down under the order of the king in 1861, the remarkable composition of its members, among other factors, indicated that Malkom Khan was very capable as a political organizer.

In addition, he had a deep knowledge of the different classes of people, because within a short time, he could gather people from all walks of life. Among those who joined Faramosh Khaneh were ex-students of Dar al Phonon, from the society's middle class and also Prince Jalal al- din Mirza, the son of Fathali Shah and the writer of Khosravan Letter (Raeen 1981). Malkom Khan also was able to attract liberal clergyman, Seyed Sadegh Tabatabaei, the father of Seyed Mohammad Tabatabaei to Faramosh Khaneh.

At the same time, Malkom Khan had written an essay of Faramoosh Khaneh which was in fact his reply to the attacks of traditional and conservative elements of the court and clergymen bent on closing Faramoosh Khaneh. In this essay, Malkom Khan claimed that there was no contradiction between Faramosh Khaneh and the principles of Islam. In fact, this essay was written to counter accusations and attacks which considered Faramosh Khaneh as being against the Islamic religion. The founding of Faramosh Khaneh was Malkom's first political activity to establish an organization based on humanism and individual rights and freedom in a traditional society. In the report of one member of the Faramosh Khaneh to Naseredin Shah and with the aim of informing the King of the activities of this association, it is stated:

These two points depend on order, and order is accomplished in ten parts: First: Life immunity, second: Possession immunity, third: Equality of rights fourth: Freedom of thought, fifth: Individual freedom, sixth: Freedom of speech, Seventh: Freedom of writing, eighth: Freedom of business, ninth: Freedom of associations, Tenth: Meritocracy (Asil, 1998, p. 25). It was for the first time that Iranians were called to demand rights and freedom. From the beginning of his activity, Malkom Khan attempted to prepare the way for the establishment of these principles of western culture and civilization in the traditional society of Iran through modernization programs. He had a relatively comprehensive understanding of reforms, as he believed that "the principles of development or progress move in consonance everywhere. Meanwhile, he placed priority on political reforms based on true understanding of the situation in Iran.

\section{Adoption of Civilization and Principles of Progress From the West and Establish Them in Iran without any Change}

It should be noted that among the intellectuals of the constitutional era (mashrooteh), Malkom Khan was more aware than others of the invasion of western culture across the world. Intellectuals like him emphasized that western countries overcame non-western countries with their culture and civilization - not by military force. In a report in 1876 to the Foreign Ministry, he observed that:

As the conditions of these days in each side show, at this time only military power to preserve the rights of governments is not sufficient. At this time 
when the propagation of new sciences and greater cooperation make the entire globe a common home for people, each government is forced to progress not only in war, but in all sciences, especially in managing their nation and country in the best way to become equal with the current civilization of the world. Each country that stops itself from this progress surely will be defeated by the progress of western countries (Malkom Khan, 1870c).

Malkom Khan views this trend of domination of the west in relation to the king in this way: if the monarch wants to maintain the current situation of the country, without doubt, he will be challenged by powerful countries because the monarch cannot continue with the current conditions.

He warned the bureaucrats of Iran that the king was forced to change the system of the government and if the king insisted on retaining this system of government, it should not be accepted, because even if the king is against the lawfulness of governance, surely the principles of the new order of the European countries will be established in Iran (Adamiyyat, 2006). Malkom Khan was aware of the necessity to accept modern civilization and the sciences of the world and closely analyzed the trend of reformation from the time of Fath Ali Shah in Iran, and also the reaction of Iranians to the culture and civilization of the West. He believed that on the one hand, Iranians prefer their own wisdom and reject all new sciences of the west but on the other hand they consider that those who have spent some short time in the West are knowledgeable and should be listened to.

In his belief, staying a few days in a European destination such as Paris increases one's wisdom, and knowledge of the sciences and progress in humans. Therefore the residents of Paris should be more aware than other people who do not have that opportunity. Modern sciences of the western countries are the best evidence of, and reference to human reason and wisdom (Asil, 2002e). He realized the success of western form of government depends on its acceptance by the people but this is not realized by Iranians who are attracted to its outer trappings but they fail to understand its underlying principles and the implications. He is adamant in stating that the Iranian government should not merely adopt the superficiality of western ways by imitation of frivolous matters (Ashouri, 1998)

In his letter to Sepahsalaar, Malkom Khan criticized the Iranian officials and government and pointed out that: "For sixty years, the government of Iran has brought instructors from European countries to train the Iranian army, but they never asked about the principles and fundamentals" (Malkom Khan, 1872). Malkom Khan repeatedly criticized this trend of superficial imitation as being useless in his articles. He concluded that in the long term, merely being influenced by the West is not real progress and in fact diminishes the power of the government (Asil, 2002d). Malkom Khan knew only too well that the main cause of this sorry state of affairs was due to imitation in a superficial way.

In his view, Iran is like a home with a damaged foundation and instead of repairing the foundation, the concern is with the repainting of the building. Instead of addressing the real cause of the problem - the foundation - they were more intent on criticizing its exterior colors which were not of much consequence (Asil, 2002d). To Malkom Khan this naive 
attitude contributed to gross inefficiency and made little or no contribution towards bettering the deplorable conditions in Iran. What was critical for him was to understand the underpinning principles. Malkom Khan criticized the superficial and temporal approach and the failure to understand and learn from the principles of western civilization by Iranian officials. He emphasized the point that this superficial understanding of western culture and civilization was the cause of Iran's weakness compared to the west. He presents his solution for this problem and proposes that Iranians should adopt western principles of order (usule nazm) or principles of European government and follow them unquestioningly:

Asians have no knowledge about the techniques for creation and managing of the government. We have no right to interfere in such an important matter by our desire or we cannot bring meaningful change. Scientists and engineers of western countries build industrial factories according to the highest level. Regulating of the government, similar to regulation of the Arabic grammar, has certain rules to it. If we really want to regulate government, we should accept and adopt these principles of orders and follow them unquestioningly (Asil, 2002b, pp. 205-206).

Malkom Khan, in his ideas of political modernization, had also considered the political structure. He believed in his article that all progress in western countries was the result of this principle. He commented that for political modernization to succeed, the Iranian government had the option to "either obey westerners, be inventors or merely imitators like their predecessors" (Asil, 2002a, p. 107). To him, the last option, to be imitators, is not acceptable if the government crisis is to be eliminated. If Iranians persist in following their predecessors the new political institutions will be meaningless. He rejects the possibility of a local solution, because in his belief, "if Iranians had want to be inventors, they should already have succeeded by that time" (p. 108) .

Malkom Khan stated that if Iranians could create inventions, such as construction of railways, they could then go on to make advances in the political system and government. He pointed out that since Iranians were unable to establish their own sciences and factories, it would be impossible for them to accomplish the far more difficult task of creating modern political structures.

While some progress has been made in the adoption of the material aspects of western civilization, the principles of European government remain entirely unknown in Iran, and the state goes about its business just as it did three thousand years ago, just as unquestioningly, as it did in adopting the telegraph. It will take another three thousand years to evolve a workable basis for the state (Asil, 2002 p. 65).

In the strategy of political modernization from above, establishment of a central powerful government is of vital importance (Bashirieh, 2000). By considering the vital importance of a government system, Malkom Khan follows this same goal and he is the first person in Iran who proposed establishing these modern political and administrative western institutions. 
This was seen by many Iranians as receiving western civilization wholesale, without any adaptation or modifications to suit local conditions. Regarding such institutions and structures, he believes that:

Whenever we say we ( Iranians) have these (western institutions), (it is said that) we have committed a big mistake, and if we want to invent or create them ourselves, it is like we want to invent the railway by ourselves (Hashemi, 2000, p. 128).

Malkom Khan expresses more clearly his opinion that:

Just as the telegraph can be imported from Europe and installed in Tehran easily, the knowledge of the western countries can be similarly received or adopted instantly in Iran. As I have said many times and will say again, if you want to invent the principles of order yourself, it is like you want to invent the science of telegraph yourself (Asil, 2002f, p. 30).

\section{Conclusion}

Malkom Khan in the first thirty years of his political activity introduced reform in the form of modernization from above. Malkom Khan, in his first significant work,,the treatise (the book of reform),emphasized the total backwardness of Iran and the growing trend of aggressive invasion of western powers. He fervently believed that the only way of saving Iran was to equip the country with a modern political structure and institutions. In a plan of political modernization from above, Malkom khan prioritized the lawfulness of government. In his book of reform (daftare tanzimat) he proposed sulatanate motlagheye montazem as a more useful government system for Iran. Although Malkom Khan emphasized that a law-based absolute monarchy would be the best type of government for Iran, he also stated that Iran's government should be based on law. Even though he accepted the absoluteness of monarchy, he disagreed with its lawlessness. So, from the beginning, Malkom Khan opposed despotism he tries careful not to declare his opposition explicitly. By being knowledgeable about the mechanism of despotism, Malkom Khan tried to prove that a lawless absolute monarchy destroyed the authority of a despotic king by spreading disorder and chaos. He declared correctly that in the lawless absolute monarchies sulatanate motlagheye gheire montazem of Asian countries two authorities for enacting laws and executing them were combined and suggested solving this problem by establishing two separate systems or structures, which was similar to separating the powers: first; the system of legislating and second; the system of executing. In line with this he proposed the introduction of the reform council (tanzimat) and council of ministers (majlis e vozara)

Malkom Khan, based on a law based government (sultanate motlagheyemontazem) created one party known as the Faramoosh Khaneh as a modern political and social institution in Iran for the purpose of organizing the political and social elites and also the political training of Dar-al-Phonoon educated men. Malkom Khan wanted to train individuals in the social and political domain who supported the modernization program on the one hand, and on the other hand, he called on the educated class, who naturally were the most suitable ones to work in 
the bureaucracy of government, in order to strengthen those already committed to bringing about modernization within the government. In fact Faramoosh Khaneh was the first political party at that era. Malkom Khan's approach in proposing the political modernization program in this period was to create modern structures and institutions, in essence, a process of statebuilding.

Malkom, in his political modernization program which gives priority to regularizing of government and modernization of structures and institutions, believed that Iranians must adopt the principles of progress from the western civilization and establish them in Iran without any change.

\section{References}

Adamiyyat, F. (2006). Andisheye Tarragi va Hokoomate Ghanoone Asre Sepahsalar (The Politics of Reform in Iran). Tehran: Kharazmi.

Adamiyyat, F. (2009). Thought of Freedom and Prelude of Constitutional Movement, Fekre Azadi Va Moghadameye Nehzate Mashrotiat. Tehran: Kharazmi.

Ajdani, L. (2007). Roshanfekrane Iran Dar Asre Mashrooteh (Iranian Intellectuals In Constitutional Era). Tehran: Akhtaran.

Akbari, M. A. (2003). Olgooye Saltanate Motlaghe ye Montazem (The Pattern of Absolute Constitutional Monarchy). Journal of History. Tehran University, 4(4), 89-110.

Algar, H. (1973). Mirza Malkum Khan: A Biographical Study to Iranian Modernism. Uc Press.

Aryanpour, S. (2000). The Life of Mirza Malkom Khan. Tehran: Ney.

Ashouri, D. (1998). Ma va Moderniteh (We And modernity). Tehran: Serat.

Asil, H. (1998). Zendegani va Andishehaye Mirza Malkom Khan Nazem al -Dowleh. Tehran: Ney.

Asil, H. (Ed.). (2002a). Resalehay e-Malkom Khan e Nazem al-Dowleh (Collected Works). Daftare Ghanoon (1st ed.). Tehran: Ney.

Asil, H. (Ed.). (2002b). Resalehay e-Malkom Khan e Nazem al-Dowleh (Collected Works). Resaley e Osoole Tarraghi. Tehran: Ney.

Asil, H. (Ed.). (2002c). Resalehay e-Malkom Khan e Nazem al-Dowleh (Collected Works). Sheikh va Vazir. Tehran: Ney.

Asil, H. (Ed.). (2002d). Resalehay e-Malkom Khan Nazem al -Dowleh. Resaleye Sheikh va Vazir. (Collected Works). Tehran: Ney.

Asil, H. (Ed.). (2002e). Resalehay e Malkom Khan Nazem al-Dowleh. Resaleye Dastgahe Divan (Collected Works) (First ed.).

Asil, H. (Ed.). (2002f). Resalehaye Malkom Khan (Malkom Khan's Booklets). Collected 
Works. (first ed. Vol. 1). Tehran: Ney.

Ghaderi, H. (2009). Andisheh Haye Digar (The Other Thoughts). Tehran: Boghe.

Gheisari, A. (2004). Roshanfekrane Iran Dar Gharne Bistom (The iranian Intellectuals In Twenteeth Centuey). Tehran: Hermes.

Goodarzi, G. (2008). Tajaddode Natamame Roshanfekrane Iran (Unfinished Modernity of Iranian Intellectuals). Tehran: Akhtaran.

Hashemi, J. (2000). Tahavolle Goftamane Roshanfekri dar Iran. Tehran: Donyae Ketab.

Isa Nia, R. (2001). Do Dore Tajrebeye No Andishi va nosai Siasi dar Iran (Master), Bagher al -Oloom, Tehran.

Malkom Khan, M. (1869). Malkom Khan's Document and Correspondence, (No 6524). Unpublished Manuscript. Central Library of University of Tehran.

Malkom Khan, M. (1870a). Malkom Khan's Document and Correspondence (No 166). Central Library of University of Tehran.

Malkom Khan, M. (1870b). Malkom Khan's Documents and Correspondence (No 170). Iranian Institution For contemporary Historical Studies.

Malkom Khan, M. (1870c). Malkom Khan To Ministry of Foreign Affairs. Malkom Khan's Documents And Correspondence Manuscripts center of Central Library of University of Tehran.

Malkom Khan, M. (1870d). [Malkom khan to Moshiroldowleh. Malkom Khan's Documents and Correspondence (No 167). Central Library of University of Tehran ].

Malkom Khan, M. (1872). Malkom khan to Sepahsalar. Malkom Khan's Documents and Correspondence (6570). Document Center of The Central Library of University of Tehran.

Malkom Khan, M. (1876a). Rasael va Mokatebate Nazem al Molk (No. 170). Documents Section of Central Library of University of Tehran.

Malkom Khan, M. (1876b). Rasael va Mokatebate Nazem al Molk (No. 173). Documents Section of Central Library of University of Tehran

Mohittabatabaei, M. (Ed.). (1948). Majmoueh-ye Asar-e MirzaMalkom Khan (Collected Works) (Vol. 1). Tehran.

Raeen, I. (1980). Faramooshkhaneh Va Faramasoonary dar Iran (Faramooshkhaneh And Freemasonary In Iran). (Vol. 2). Tehran.

Raeen, I. (1981). Zendegi Va Koosheshhaye siasi Malkom khan. Tehran: amir kabir.

Saeedi, G. (2002). Mirza Malkom Khan, Sonnat va Moderniteh. Tehran: Akhtaran.

Safari, M. A. (1998). Mashrooteh Sazan. Tehran: Elm. 


\section{Copyright Disclaimer}

Copyright reserved by the author(s).

This article is an open-access article distributed under the terms and conditions of the Creative Commons Attribution license (http://creativecommons.org/licenses/by/3.0/). 